Article

\title{
Benthic Marine Ciliate Assemblages from Southern Brazil and Their Relationship with Seasonality and Urbanization Level
}

\author{
Luana D. Tarragô, Pedro M. A. Ferreira and Laura R. P. Utz * \\ Graduate Program in Ecology and Evolution of Biodiversity, School of Health and Life Sciences, PUCRS, \\ Porto Alegre 90619-900, RS, Brazil; luanadottot@gmail.com (L.D.T.); pedro.abreu@pucrs.br (P.M.A.F.) \\ * Correspondence: laura.utz@pucrs.br
}

Received: 22 November 2019; Accepted: 15 December 2019; Published: 31 December 2019

\begin{abstract}
Sandy beaches represent two-thirds of littoral zones worldwide. Complex factors such as winds, waves, and sediment characterize this environment. Ciliophora is one of the most diversified unicellular eukaryotic phyla and, in marine sediments, can reach 40 species per $\mathrm{cm}^{3}$. Despite its importance, knowledge about interstitial communities is still lacking. In the present work, we characterized the assemblage of interstitial ciliates from sandy beaches in the north coastal area of Rio Grande do Sul state, southern Brazil. Fourteen sampling sites distributed along the swash zone of seven beaches with different degrees of urban development were sampled over the course of one year. At each site, eight sediment samples were taken, and a total of 51 species distributed in 37 ciliate genera were identified. Classes Spirotrichea (29\%) and Karyorelictea (21\%) accounted for $50 \%$ of ciliate species richness, with the highest richness being observed within the context of an intermediately urbanized setting. Community analyses revealed that ciliate community is influenced by urbanization degree and season, with distinct assemblages occurring in highly urbanized areas. In beaches affected by a high level of human activity, disturbance effects increased diversity, while in areas showing a milder influence of urbanization, the level of disturbance may be low, resulting in lower richness.
\end{abstract}

Keywords: benthos; benthic ecology; marine ecology; coastal zone

\section{Introduction}

Sandy beaches represent two-thirds of littoral zones and are extremely dynamic environments in which the interaction of winds, waves, tides, and sand are responsible for their characteristic instability [1]. The interstitial environment, i.e., the space between sediment particles, corresponds to $40 \%$ of the total sand volume on a beach, and has a long list of features (e.g., grain size, porosity, moisture content, etc.) which influence its characteristics. Its biota may be highly diverse, including fungi, bacteria, protozoans, and metazoans. Ciliophora is one of the most conspicuous and diverse groups of unicellular eukaryotes [2] and, in the interstitial environment, it is present at very high abundance, especially on beaches with fine sand [3]. Furthermore, it has been estimated that the abundance of microorganisms is higher in the interstice than in the water column [4].

Despite the high diversity of marine organisms recorded in Brazil (approximately $65 \%$ of known animal species are marine (insects excluded), [5]), few areas on the Brazilian coast have been surveyed so far. When it comes to the interstitial biota of sandy beaches, most studies have focused on macrofauna and meiofauna (e.g., [6-9]), with only a few records of marine interstitial ciliates having been reported [10-12].

Across the world, approximately 3.6 billion people were living no more than $100 \mathrm{~km}$ away from coastlines at the end of the last century [13]. The urban development of coastal areas increases 
modifications to shorelines; these modifications have evolved from some accidental actions to direct changes in response to population needs [1]. The release of domestic sewage in natura, inorganic pollutants, changes in turbidity, excess of suspended solids, and habitat changes are examples of the effects of the development of coastal areas which may impact the biota through individual or synergistic effects [14]. For phytoplankton, for example, researchers have cited the release of continental effluents as a cause for the observed decrease in its global abundance [15]. In developing and underdeveloped countries, which are mostly located in the southern hemisphere, occupancy rates in coastal areas are greater than those in developed countries [16]. Rio Grande do Sul state, in southernmost Brazil, has approximately $600 \mathrm{~km}$ of shoreline, of which the northern section is the most populous. Urban development in this area has grown significantly over the past 50 years and, consequently, environmental problems have increased [17].

In a review monograph, McLachlan and Brown [1] proposed that the coastal environments of the world may be divided into four categories, according to the level of anthropic influence on beach landscapes. The first category would encompass almost pristine beaches where there are still dunes of considerable size, but which are already suffering from small levels of damage by trampling, for example. In the second category, the landscape presents consistent modifications; there is considerable decrease in dune size and number in favor of leisure areas. In categories three and four, restoration efforts for beach nourishment (sand replacement) and erosion retaining are imperative. The authors note that most beaches in developing countries such as Brazil are in the second category.

Moura et al. [17] carried out a study on urban development in the northern coast of Rio Grande do Sul state, and classified the municipalities into four profiles (permanent municipalities, urban for second residence, urban agricultural, and rural municipalities). Beaches with lower degrees of urbanization (second residence profile) still retain considerable dunes and are used relatively rarely; such beaches are typically in category one of McLachlan and Brown's classification [1]. Beaches with stretches without dunes and a considerable permanent population, which exposes the area to greater use, are considered permanent municipalities according to Moura et al. [17], and are in category two of development [1].

Although Ciliophora is one of the most abundant unicellular eukaryotic phyla, knowledge about its richness and ecological relationships in the interstitial marine habitat is still incipient. In Brazil, only three descriptive studies published so far have focused on marine ciliates [10-12], despite the size and diversity of the Brazilian coast. Studies that evaluate the influence of coastal urban development on microbenthic interstitial biota are rare, even internationally. Gheskiere et al. [18] analyzed the meiofauna and nematofauna response to tourism-induced changes in sandy beaches. Harguinteguy et al. [19] surveyed the differences in meiofauna community structure in beaches that were far or near from harbor activity. When it comes to marine interstitial ciliate communities specifically, no study has been published to date that relates how abiotic characteristics of beaches with dissimilar degrees of urbanization influence composition and other community descriptors.

Therefore, the main goals of the present study were to investigate community-level descriptors of interstitial marine ciliates (species composition, richness, and diversity), and to characterize the relationships between urban development levels and these descriptors in exposed sandy beaches on the coast of Rio Grande do Sul state, southern Brazil.

\section{Materials and Methods}

\subsection{Sampling}

A total of 14 sites were sampled in the swash zone of seven beaches (Arroio do Sal, Cidreira, Magistério, Bal. Pinhal, Sta Rita, Torres, and Tramandaí) from northern Rio Grande do Sul state (RS), Brazil (two sampling sites $\sim 500 \mathrm{~m}$ apart from each other on every beach) (Table 1, Figure 1). These flat, low-energy beaches are under a microtidal regime, and present morphodynamic states ranging from intermediate to dissipative [20] and fine sand $(0.2 \mathrm{~mm})$ [21]. The average wave height is about 
$1.5 \mathrm{~m}$ [22], and the beaches are subjected to a humid, subtropical climate, which is strongly influenced by masses of polar and subtropical air [23].

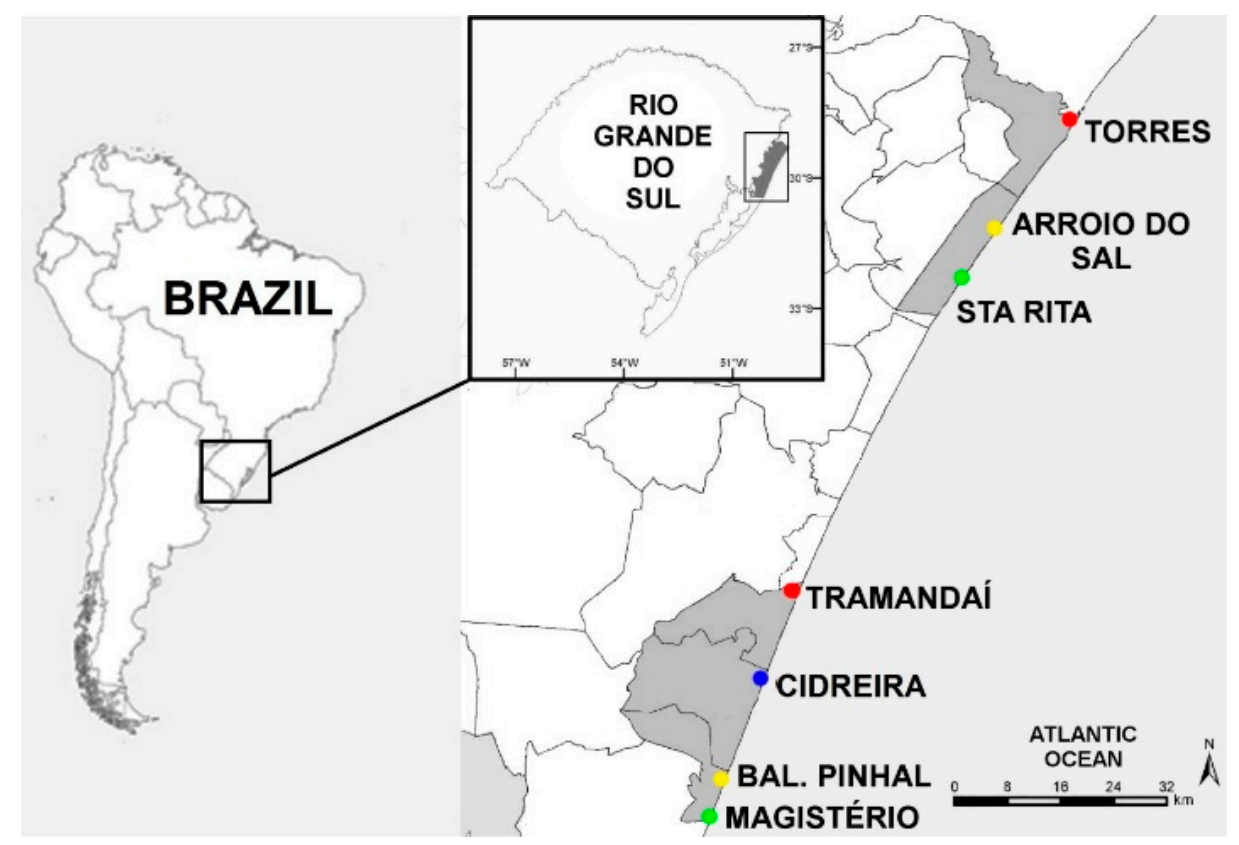

Figure 1. Geographic location of the seven northern Rio Grande do Sul beaches where the study was developed. Red dots = high degree of urbanization, yellow dots = intermediary degree, green dots $=$ low degree, blue dot $=$ almost null urbanization .

Table 1. Urban development classification and density of residences near the collection site for the beaches from northern Rio Grande do Sul state (RS), Brazil.

\begin{tabular}{cccc}
\hline Class & $\begin{array}{c}\text { Urbanization } \\
\text { Degree }\end{array}$ & Beaches & $\begin{array}{c}\text { Density of Residences } \\
\text { Close to the Collection Site }\end{array}$ \\
\hline $\begin{array}{c}\text { Urban with permanent population } \\
\text { Urban with permanent population }\end{array}$ & High & Torres & High \\
Urban base for second residence & Intermediary & Tramandaí & Arroio do Sal \\
Urban base for second residence & Intermediary & Bal. Pinhal & Low \\
Pristine beaches & Low & Magistério & Low \\
Pristine beaches & Low & Sta Rita & Very Low \\
Dune Field & Almost null & Cidreira & Very Low \\
\hline
\end{tabular}

Beaches were chosen according to degrees of urban development in order to assess relationships between ciliate assemblage composition and some environmental parameters that may be directly affected by human activities. Moura et al. [17] classified RS northern beaches into four classes according to their urbanization and, for the purpose of this study, two are very important: Urban with permanent population and urban base for second residence (municipalities in which less than $20 \%$ of the houses are occupied permanently). The first class represents midsize towns with population between 30,000 and 40,000 people, with most of the households being occupied throughout the year. The second class is composed of small towns with population between 10,000 and 20,000 people, with only $20 \%$ of households being occupied throughout the year. For the purpose of this study, two other classes were added: Pristine beaches and a dune field. Pristine beaches encompass small municipalities and the other category is a dune field belonging to Cidreira beach. This area has almost null urbanization and sampling points were plotted right in the middle where the closest residences were at least $2 \mathrm{~km}$ distant (Figure 2). 


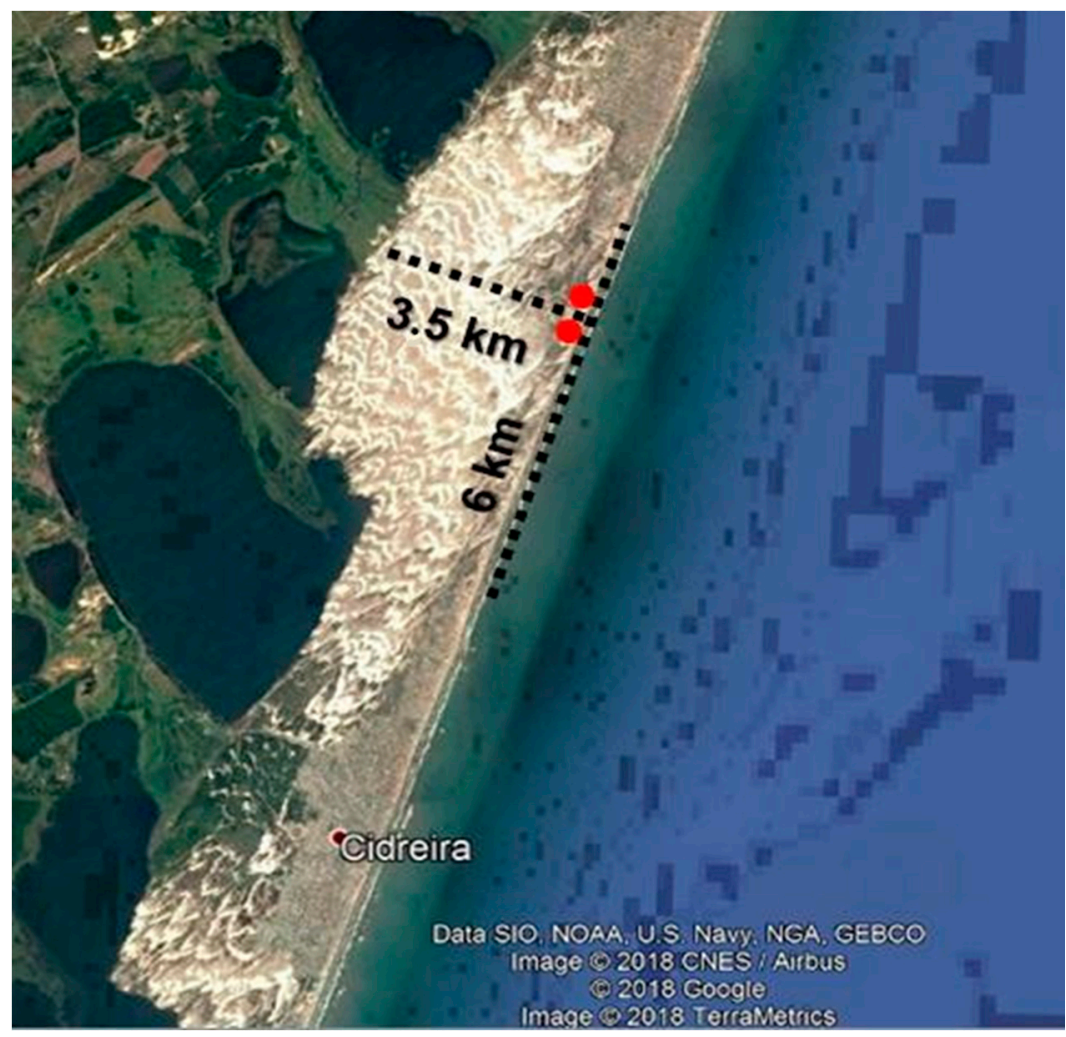

Figure 2. Dune field (Cidreira beach) location showing its distance from urbanized areas (Google Earth, 2017). Red dots = sampling points.

Eight sampling campaigns were carried out: Two in the winter, two in the spring, two in the summer, and two in the autumn. At each sampling site, 12 subsamples were taken with a PVC (polyvinyl chloride) tube of $10 \mathrm{~cm}$ in length and $3 \mathrm{~cm}$ in diameter. Although Rio Grande do Sul state presents a micromareal tidal range, samples were always taken during neap tide to ensure the standardization of sampling campaigns. To find the exact place to sample, the mean wavelength of 20 spreading waves was calculated before sampling. To perform this calculation, a measuring tape was fixed between the infralittoral zone and the swash zone. Lengths of 20 waves were taken, and the arithmetic mean was calculated to define the exact sampling site. These procedures were repeated for all sampling points. After collection, samples were stored in thermal boxes and taken to the laboratory.

Four subsamples were maintained under refrigeration $\left(\sim 6-10^{\circ} \mathrm{C}\right)$ for ciliate qualitative evaluation, and four others were fixed using Lugol 10\% [24] for ciliate quantification. One milliliter of each fixed sample was counted using a Sedgwick-Rafter counting cell chamber. Subsamples were counted until 300 individuals from a single Ciliophora taxon were computed [25]. After sampling, extractions of the organisms from the sediment were carried out in the laboratory using the Uhlig's modified method [26]. The organisms were observed in vivo using an optic microscope (in the first $30 \mathrm{~min}$, after $24 \mathrm{~h}$ and $48 \mathrm{~h}$ ), and taxonomic determination was performed using specific literature such as Carey [27], Dragesco and Dragesco-Kernéis [28], Wanick and Silva-Neto [12], Xu et al. [29,30], and Yan et al. [31].

\subsection{Environmental Parameters}

Two samples to analyze chlorophyll $a$ were collected with a PVC tube $(1 \times 1 \mathrm{~cm})$ from each sampling site. To evaluate the organic matter percentage of the sediment, two samples with $\sim 10 \mathrm{~g}$ were taken using a spoon at each sampling site. Water temperature $\left({ }^{\circ} \mathrm{C}\right)$ and conductivity $(\mathrm{mS} / \mathrm{cm})$ were measured twice at each sampling site using a portable probe (SANXIN model SX751). Chlorophyll $a$ and organic matter data were measured following Golterman et al. [32] and Allen [33], respectively. For the chlorophyll $a$ analyses, the sample volume was $1 \mathrm{~mL}$. 


\subsection{Data Analyses}

Ciliate community data were summarized in a community matrix using mean abundance values of each season for the seven sampling sites (28 sampling units). We used this community matrix to calculate ciliate diversity using Simpson's index (1-D, [34]), and to perform an ordination with nonmetric multidimensional scaling, based on Bray-Curtis dissimilarity between sampling units. In addition, we constructed a clustered heatmap showing similarities between sampling sites, based on a binary species matrix (presence/absence of species at each site). For clustered heatmap construction, we used the package 'pheatmap' [35], with the complete linkage clustering criterion based on Euclidean distances between sites. We tested if ciliate communities differed between seasons and levels of urbanization with a multivariate analysis of variance (MANOVA) with permutation, considering both factors and their interaction. These analyses were carried out and plotted with packages 'vegan' and 'ggord', respectively [36]. Finally, we tested the relationship between urbanization level and sampling season on community descriptors, using linear mixed effect models (LMM), including beach identity (i.e., the seven sites) as a random variable. For these analyses, we used package 'nlme' [37]. We used Tukey's post hoc test to identify pairwise differences between seasons and/or urbanization levels in statistically significant models.

We also tested the effects of environmental variables on ciliate community composition, species richness, and diversity. Environmental parameters (chlorophyll $a$, temperature, conductivity, organic matter, and the level of urbanization) were pooled in a matrix describing 28 sampling units (four seasons at seven sampling sites). To estimate the effect of environmental variables on species composition, we used the environmental matrix, coupled with the community matrix, to perform a constrained correspondence analysis (CCA). In this analysis, the transformed community matrix (chi-squared) was subjected to weighted linear regression considering the environmental variables as predictors, with the fitted scores submitted to correspondence analysis [38]. The resulting model was submitted to an analysis of variance with permutation (10,000 iterations) to estimate significance, and the constrained ordination scores (sampling units, species, and environmental variables) were plotted on a two-dimensional scatterplot. Finally, we tested the influence of environmental variables on ciliate species richness and diversity using linear mixed effect models, including beach identity as a random variable.

We assessed the relationship of species composition with (1) sampling season and (2) level of urbanization of sampling sites, using the 'IndVal' indicator species approach (package 'indicspecies', [39]). This analysis estimated the strength of the association between each species and the groups of sampling units defined a priori, and the statistical significance of each pairwise association $[39,40]$. For the statistical significance tests, we used crisp membership values for both grouping criteria, and the site-based approach for null hypothesis, which considered that the abundance of the species at sites from the same group was not higher than the abundance at sites that belonged to other groups. We reported only significant indicator species ( $p<0.05$, considering Sidak's correction for multiple testing). When a species was significantly associated to more than one season or urbanization level, we reported only the association with the highest strength value. All data analyses were carried out in the R environment.

\section{Results}

We analyzed 224 samples for ciliate taxa determination. A total of 51 species distributed among 37 genera and 10 classes could be observed during the study (Table S1). Classes Spirotrichea (29\%) and Karyorelictea $(21 \%)$ accounted for $50 \%$ of the ciliate species richness in the study area. Within Spirotrichea, subclasses Hypotrichia and Stichotrichia had the highest number of species: Seven and six, respectively. Species in the class Karyorelictea were the most frequent organisms present in the samples, with orders Protostomatida (3 spp.) and Loxodida (2 spp.) having the highest number of sampled species.

Arroio do Sal was the beach with highest mean species richness, while the others presented a similar pattern (Figure 3). The clustered heatmap based on presence and absence of species showed interesting patterns among sampled beaches (Figure 4). Beaches with high and intermediate degrees of urbanization clustered together, while those with low or almost null urbanization formed a separate group. 


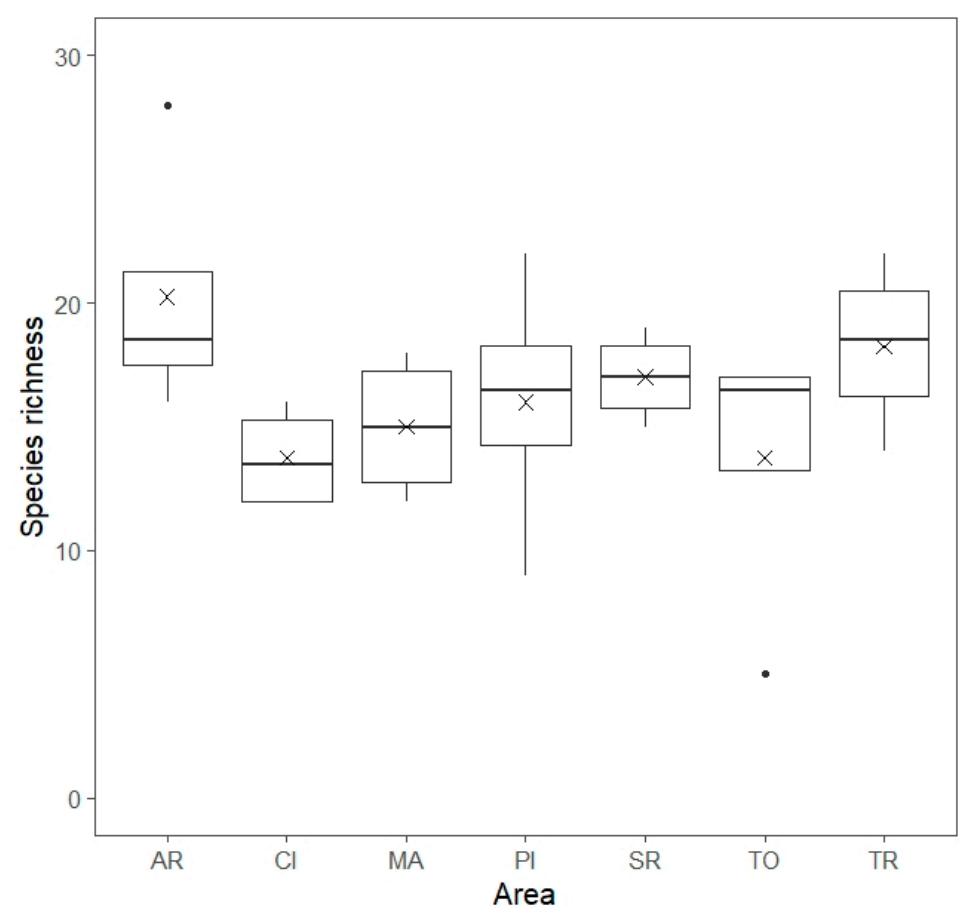

Figure 3. Ciliophora species richness for seven beaches from northern Rio Grande do Sul state (RS), Brazil, based on data collected during the study period (June 2016 to July 2017). Mean richness values are indicated with an ' $X$ ' inside boxplots. (AR: Arroio do Sal (intermediate degree of urbanization), CI: Cidreira (null degree of urbanization), MA: Magistério (low degree of urbanization), PI: Pinhal (intermediate), SR: Santa Rita (low degree of urbanization), TO: Torres (high degree of urbanization), TR: Tramandaí (high degree of urbanization)).

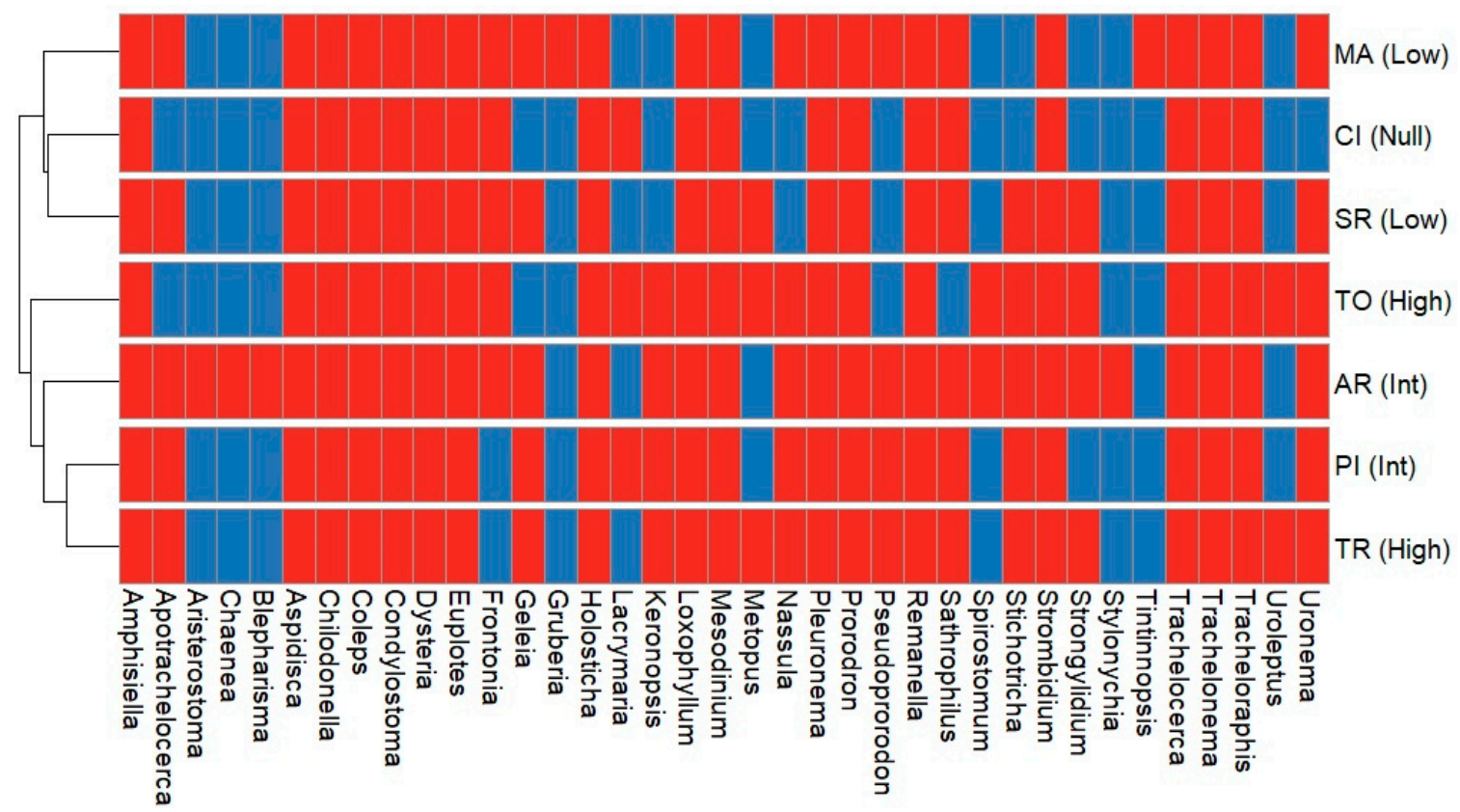

Figure 4. Clustered heatmap based on data collected from seven northern Rio Grande do Sul state (Brazil) sites during the study period (June 2016 to July 2017). Clustering criterion was complete linkage, based on Euclidean distances between sites. Colors represent presence (blue) or absence (red) of species in each site (AR: Arroio do Sal, CI: Cidreira, MA: Magistério, PI: Pinhal, SR: Santa Rita, TO: Torres, TR: Tramandaí). 
A Venn diagram (Figure 5) shows that 26 of the 31 genera identified in the present work occurred in all areas with different degrees of urban development. Only Cidreira had zero exclusive taxon, and the genus Lacrymaria was shared exclusively with areas with high degree of urban development. Table 2 shows the genera shared among sampled areas.

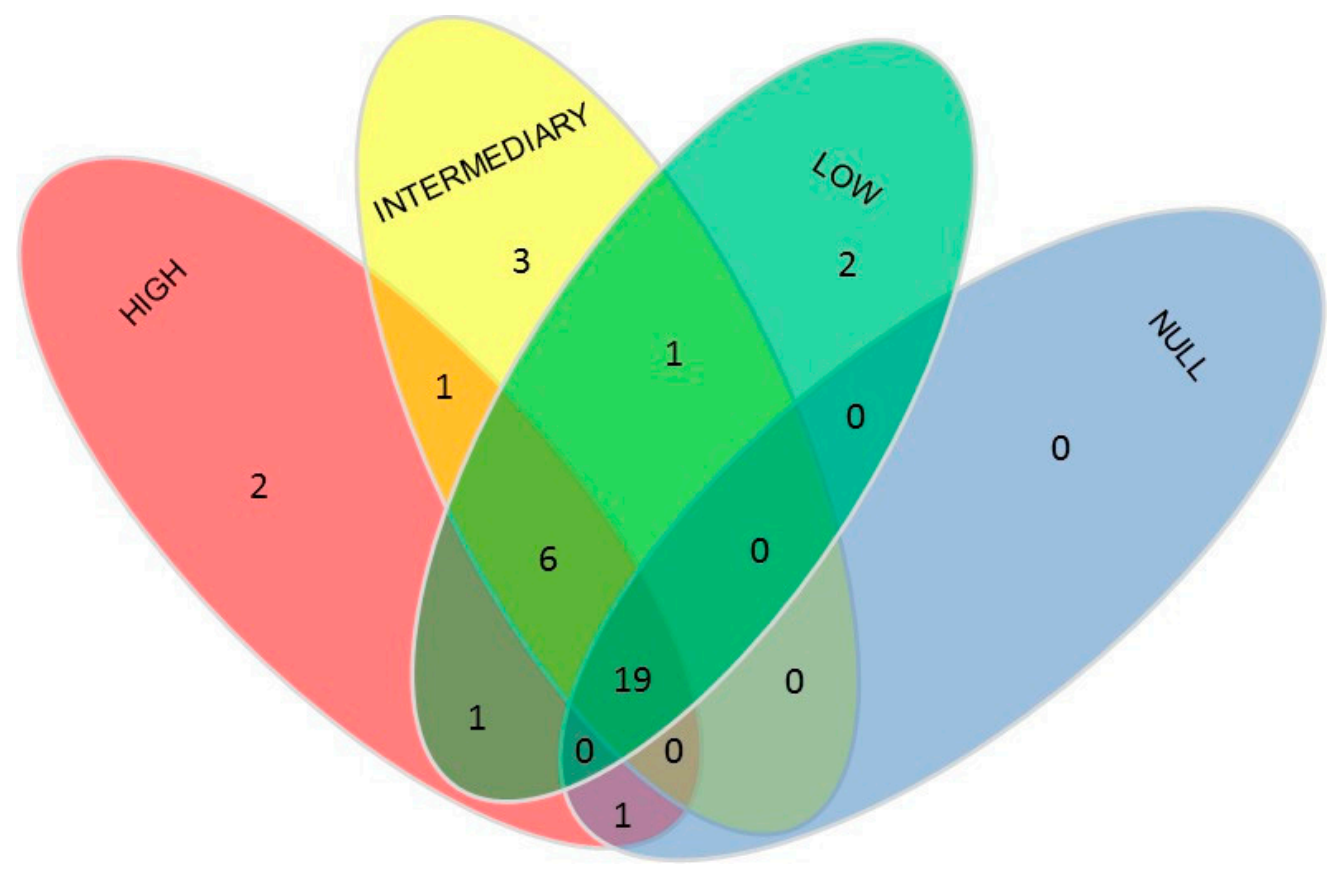

Figure 5. Venn Diagram for the occurrence of marine interstitial ciliates genera in the four degrees of urban development of sandy beaches in northern Rio Grande do Sul state (RS), Brazil, based on data collected during the study period (June 2016 to July 2017).

Table 2. Genera shared or exclusive from the areas with different degrees of urban development observed between June 2016 and July 2017 in sandy beaches from northern Rio Grande do Sul state.

\begin{tabular}{cc}
\hline Areas & Shared Taxa \\
\hline High $\times$ Intermediary & Uroleptus \\
High $\times$ Low & Strongylidium \\
High $\times$ Null & Lacrymaria \\
Geleia & Antermediary $\times$ Low \\
High $\times$ Intermediary $\times$ Low & Apotrachelocerca, Holosthica, Nassula, Pseudoprorodon, Spirostomum, Stichotricha \\
High $\times$ Intermediary $\times$ Low & Amphisiella, Aspidisca, Chaenea, Chilodonella Coleps, Condylostoma Dysteria, \\
$\times$ Null & Euplotes,Frontonia, Loxophyllum, Mesodinium, Pleuronema, Prorodon, Remanella, \\
Degree of Urbanization & Sathrophilus, Strombidium, Trachelocerca, Trachelonema, Tracheloraphis, Uronema \\
High & Exclusive Taxa \\
Intermediary & Keronopsis, Metopus \\
Low & Aristerostoma, Stylonchia, Blepharisma \\
& Tinntinopsis, Gruberia \\
\hline
\end{tabular}

Temperature, chlorophyll $a$, conductivity, species richness, and species diversity differed between seasons, whereas organic matter did not. Moreover, none of these variables differed between urbanization levels (Table 3, Figure 6). Chlorophyll $a$ values were significantly higher during the winter in comparison with the other seasons. Values of temperature and conductivity were significantly different along the seasons, while species richness differed between winter and summer and winter and autumn. Species diversity presented a statistically significant difference between autumn and summer (Table 3, Figure 6). 

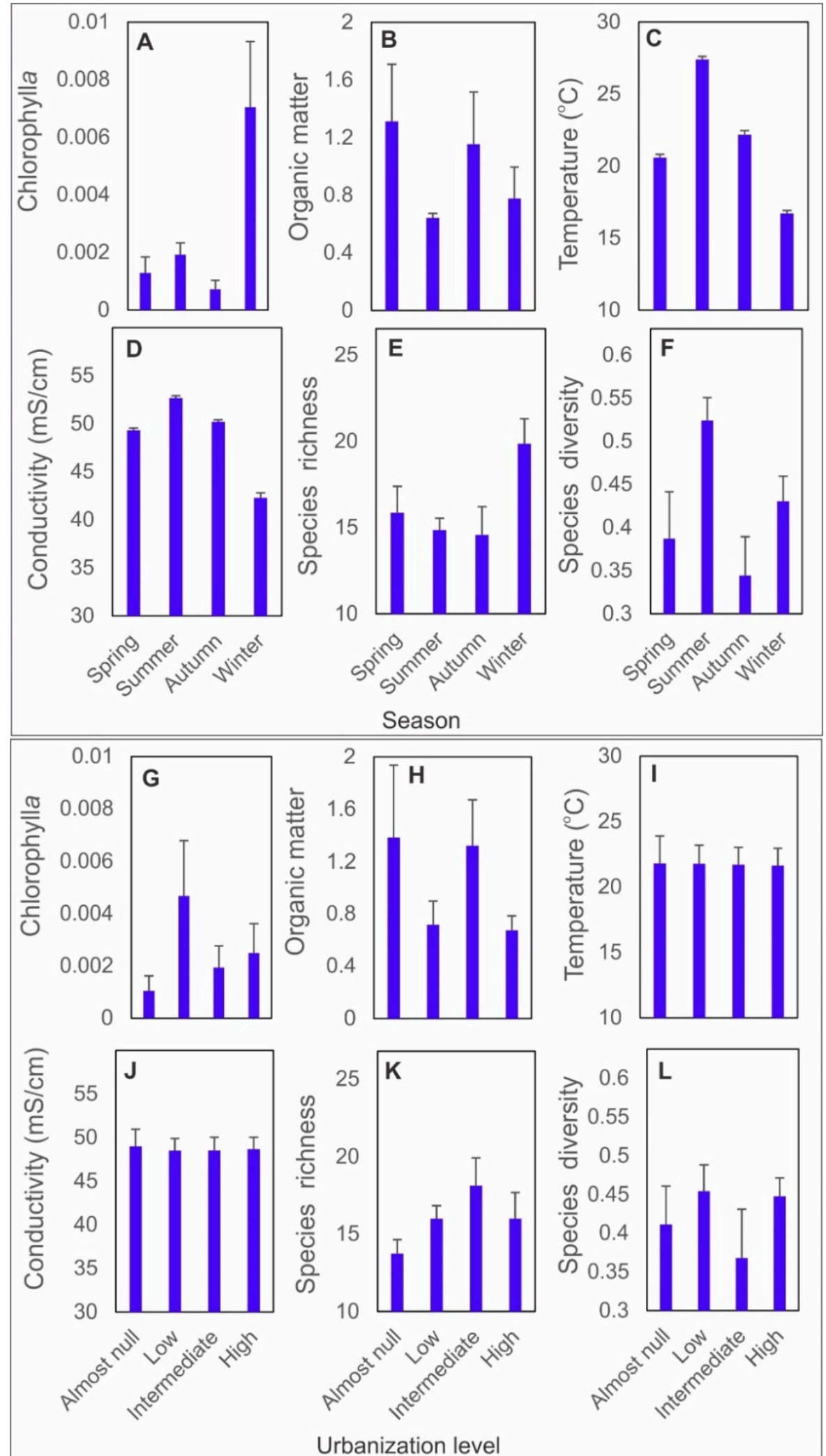

Figure 6. Chlorophyll a, organic matter, temperature, conductivity, species richness, and species diversity of benthic ciliate assemblage along the seasons (panels $\mathbf{A}$ to $\mathbf{F}$ ) in the four urbanization categories (panels $\mathbf{G}$ to $\mathbf{L}$ ). Temperature and diversity differed between seasons (GLM (Generalized Linear Model) $\mathrm{F}=290.178, p=0.0001, \mathrm{~F}=2.9976, p=0.048$, respectively) but not between urbanization levels (GLM F $=0.218, p=0.6603, \mathrm{~F}=0.0022, p=0.9647$, respectively). 
Table 3. Statistics of linear mixed effect models with two independent variables (urbanization and season) and their effect on abiotic and biotic descriptors of ciliate communities. Pairwise results of Tukey's post hoc test provided below for significant models. Values in bold are statistically significant. Legend for pairwise contrasts: W: Winter, Sp: Spring, Su: Summer, A: Autumn.

\begin{tabular}{|c|c|c|c|c|}
\hline \multirow{2}{*}{ Descriptors } & \multicolumn{2}{|c|}{ Urbanization } & \multicolumn{2}{|c|}{ Season } \\
\hline & F-Value & $p$-Value & F-Value & $p$-Value \\
\hline Temperature & 0.2180 & 0.6603 & 290.1780 & 0.0001 \\
\hline Chlorophyll $a$ & 0.0355 & 0.8580 & 5.0841 & 0.0101 \\
\hline Organic matter & 0.6369 & 0.4610 & 0.9918 & 0.4190 \\
\hline Species richness & 0.6377 & 0.4608 & 3.0878 & 0.0434 \\
\hline Species diversity & 0.0022 & 0.9647 & 2.9976 & 0.0480 \\
\hline Conductivity & 0.0600 & 0.8122 & 180.2800 & 0.0001 \\
\hline \multicolumn{5}{|c|}{ Tukey's Post-Hoc } \\
\hline Temperature & \multicolumn{4}{|c|}{ All contrasts significant $(p<0.0001)$} \\
\hline Chlorophyll $a$ & \multicolumn{4}{|c|}{ W-Sp $(p=0.0026)$, W-Su $(p=0.0104)$, W-A $(p=0.001)$} \\
\hline Species richness & \multicolumn{4}{|c|}{ W-Su $(p=0.0262)$, W-A $(p=0.016)$} \\
\hline Species diversity & \multicolumn{4}{|c|}{$\mathrm{A}-\mathrm{Su}(p=0.0088)$} \\
\hline Conductivity & \multicolumn{4}{|c|}{ All contrasts significant $(p<0.0001)$, except A-Sp } \\
\hline
\end{tabular}

Community composition of ciliates was affected by both season (MANOVA: Sum of squares $=0.1954, \mathrm{~F}=2.4645, p=0.001$ ) and urbanization degree (Sum of squares $=2.1922, \mathrm{~F}=9.2150$, $p=0.046$ ) (Figure 7A,B). The interaction between season and urbanization was not significant (sum of squares $=0.2624, \mathrm{~F}=1.1032, p=0.384$ ). Beaches with a high degree of urbanization had a different community composition when compared with other urban levels (Figure 7A). In relation to season, summer and autumn shared a similar community composition, while spring and winter were more similar to each other (Figure 7B). Among species present in the ciliate community, we could detect those that were indicators for season and urbanization degree. Figure $7 \mathrm{C}$ shows a list of indicator species $(p<0.005)$ found in the different urban levels and seasons.
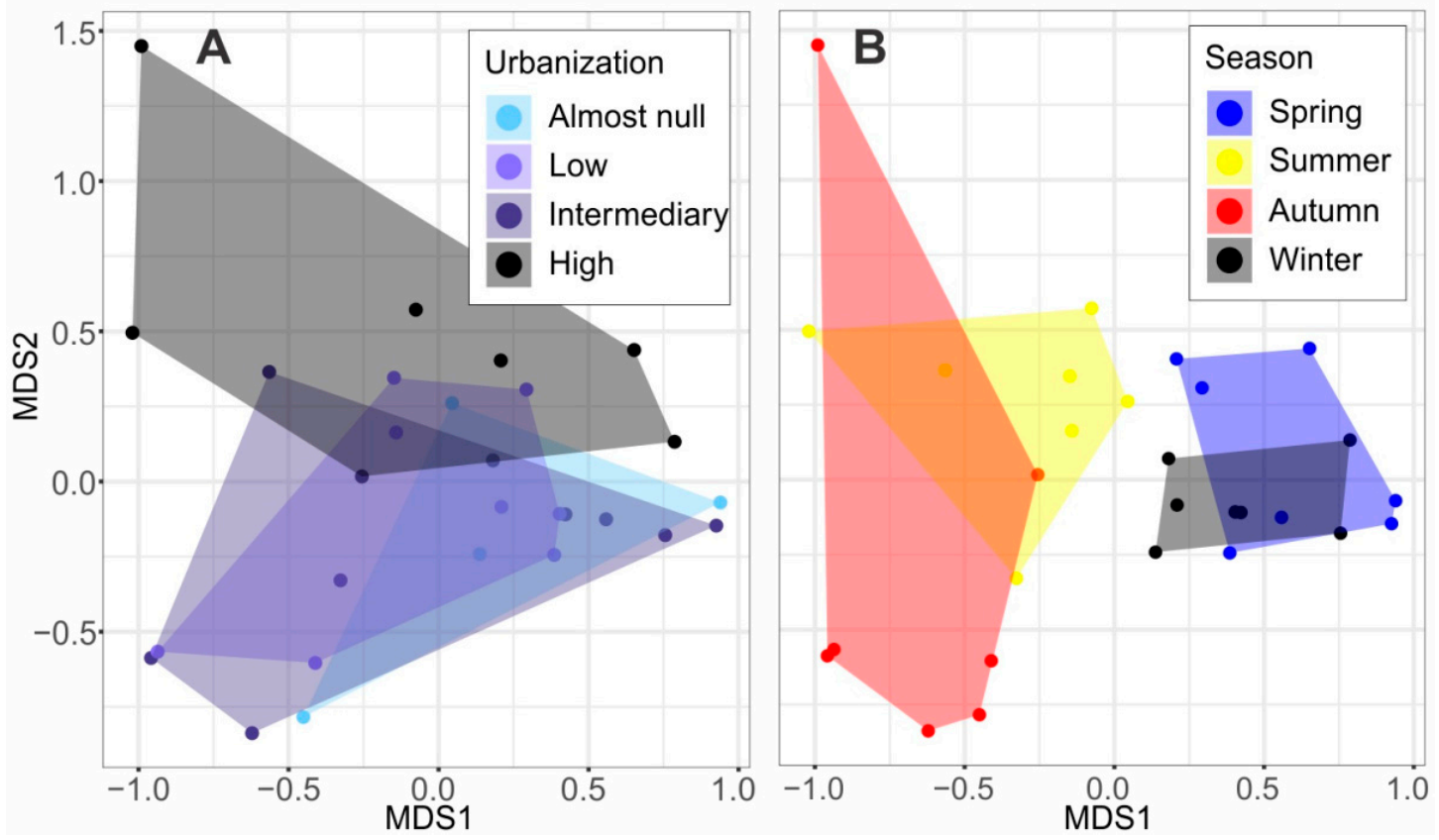

Figure 7. Cont. 


\begin{tabular}{|l|l|}
\hline C Indicator species & Spring \\
\hline & Euplotes \\
\hline Almost null & Summer \\
\hline Lacrymaria & Euplotes \\
\hline Low & Pseudoprorodon \\
\hline Apotrachelocerca & Trachelocerca \\
Condylostoma & Autumn \\
\hline Intermediary & Remanella \\
\hline Nassula & Strombidium \\
Trachelonema & Winter \\
\hline Tracheloraphis & Chilodonella \\
High & Frontonia \\
\hline Metopus & Holosticha \\
\hline & Loxophyllum \\
& Nassula \\
\hline & Pleuronema \\
\hline & Prorodron \\
\hline & Stichotricha \\
\hline
\end{tabular}

Figure 7. Ordination scatterplots obtained from a nonmetric multidimensional scaling analysis of the benthic ciliate community, using the Bray-Curtis distance index. Stress $=0.0859$ for both ordinations. Sampling units identified according to urbanization degree (A) and sampling season (B). Indicator species present in beaches with different degrees of urbanization and season $(\mathbf{C})$.

The constrained correspondence analysis revealed a significant relationship between the ciliate community composition matrix and the environmental matrix (chi-square $=0.2049, \mathrm{~F}=1.6628$, $p=0.0482$; Figure 8). Among the individual environmental variables, conductivity showed a significant influence on ciliate species richness (LMM F $=8.1775, p=0.0109)$, with lower species richness under higher conductivity values (Figure 9A). In addition, ciliate species diversity increased with temperature (LMM F = 3.4317, $p=0.0426$; Figure 9B).

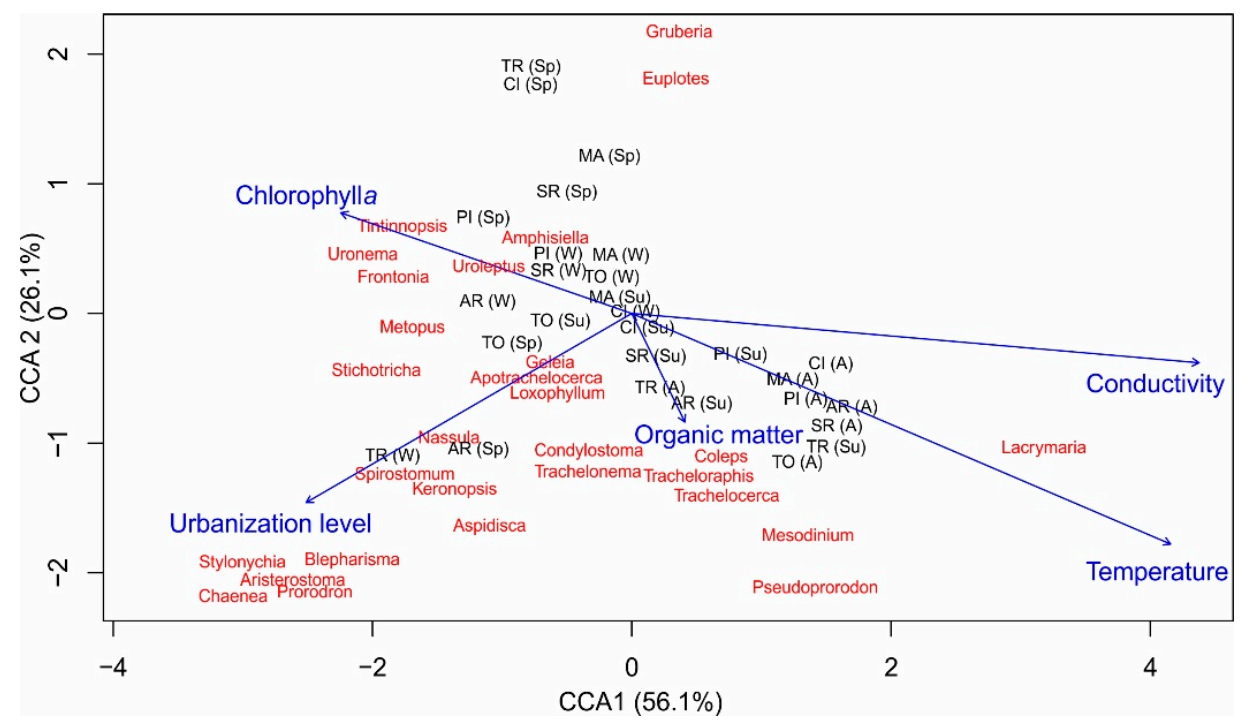

Figure 8. Ordination scatter plot obtained from a constrained correspondence analysis (CCA) of the benthic ciliate community. Ciliate taxa in red, environmental variables in blue, and sampling units in black. Sampling unit labels comprise site (AR: Arroio do Sal, CI: Cidreira, MA: Magistério, PI: Pinhal, SR: Santa Rita, TO: Torres, TR: Tramandaí) followed by season (Sp: Spring, Su: Summer, A: Autumn, W: Winter). 

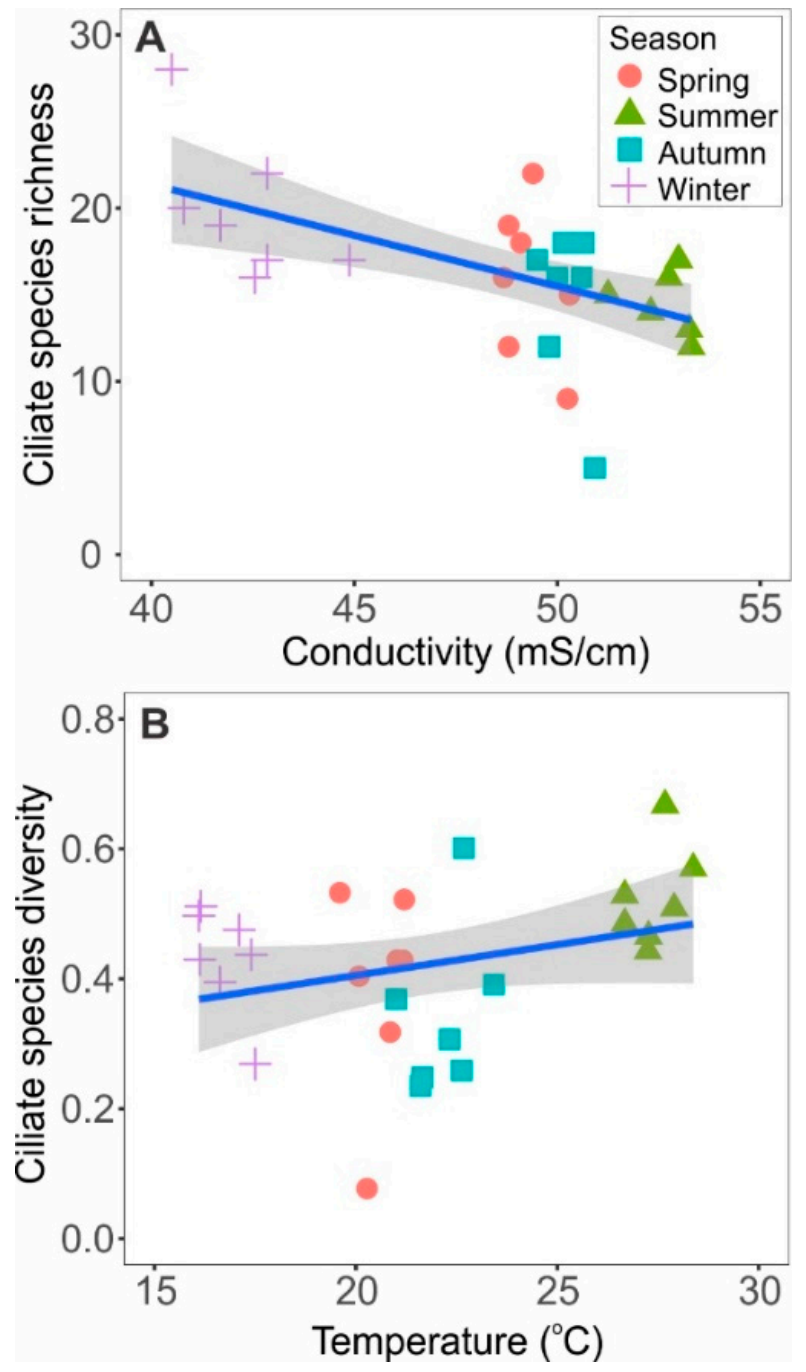

Figure 9. Relationships between benthic ciliate community descriptors and environmental variables. (A) Species richness (number of species) and conductivity. (B) Species diversity (Simpson's 1-D) and temperature. Sampling plots identified according to season.

\section{Discussion}

Studies on taxonomy and ecology of marine ciliates are advanced in many parts of the world when compared to Brazil. Azovsky and Mazei [41] used a comprehensive database to evaluate the diversity and distribution of benthic ciliates worldwide, and no records were found for the entire Brazilian coast. The assessment of ecological interactions between species in the microbenthos is also lacking. While seasonal patterns of succession in benthic marine communities were investigated in several beaches in the Northern Hemisphere, this type of data is very rare for beaches in the Southern Hemisphere [41]. Studies on the ecology of microbenthos have pointed out that these communities are shaped by interaction between species, but are strongly influenced by abiotic factors. Fenchel [42], in one of the pioneering studies on benthic ciliates from the Baltic Sea, observed that these organisms play a key role on bacterial removal but are very susceptible to local changes in the concentration of dissolved oxygen and other environmental factors. Santangelo and Luchesi [43] observed that temperature, salinity, and grain size were also important factors shaping the ciliate benthic community in the Mediterranean Sea. In a long-term study in the White Sea, Burkovsky and Mazei [44] could follow the succession of interstitial ciliates and linked the changes in community assemblage to environmental factors. These, acting together, could lead to a different and more mature ciliate assemblage in the 
investigated environment. Parallel to ecological approaches, several studies have also characterized and described several species of interstitial ciliates [28-30,45-49].

In Brazil, only three studies have assessed the interstitial marine ciliate diversity: Kattar [10], Warnick and Silva-Neto [12], and Paiva et al. [11]. These surveys were performed in two beaches of the southeastern region and in one beach of the northeastern region of the country, while data for the rest of the Brazilian coastline are still lacking. The number of different genera found in these three studies ranged from 23 to 38 , with 32 to 75 species identified. The present study was the first developed in southern Brazil, and found a similar diversity to that observed in other Brazilian regions. In relation to species composition, several species were shared with other regions of the world, but considering that the Brazilian coast has more than $7000 \mathrm{~km}$ in extension, with different types of beaches, there are still many areas that remain unexplored. For this reason, it is reasonable to assume that there are still many marine ciliate species to be determined and described from the Brazilian coast.

Frequent genera, such as Tracheloraphis, Remanella, Coleps, and Pleuronema, could be seen as common inhabitants of sandy beaches. In a one-year study, Santangelo and Lucchesi [48] were able to detect eight genera (Trachelocerca, Trachelonema, Tracheloraphis, Remanella, Coleps, Lacrymaria, Frontonia, and Pleuronema) of marine ciliates as residents (i.e., taxa observed throughout the whole year) in the Mediterranean coast of Italy. Except for Frontonia, the other seven genera were also observed with high frequency on the beaches surveyed in the present study. Lacrymaria was present only in summer and winter, while the other six genera were observed during the whole year.

The conspicuous presence of the karyorelictean genera Trachelocerca, Trachelonema, Tracheloraphis, and Remanella corroborates the idea of a close relationship between morphology of the group (flat and elongated body, head-like anterior end, etc.), the interstitial habit, and the marine environment [2]. Giere [4] classified the class Karyorelictea as "microporal" ciliate inhabitants, which means that there is a preference by these organisms to colonize systems with fine to medium grain size (120-400 $\mu \mathrm{m})$, the same grain size range found in Rio Grande do Sul beaches. Giere [4] also recognized Hypotrichia as mesoporal taxa, suggesting that, given their oval to slightly flattened forms, organism mobility would be facilitated in a habitat with large pore diameter $(400-1800 \mu \mathrm{m})$. Also, he suggested that the thick and armored pellicle characteristic of hypothrichs can provide protection against wave exposure. Body protection in general is an important feature of benthic species inhabiting dissipative beaches, where the waves are constantly swashing the shoreline [1]. These considerations help to understand the richness of Hypotrichia and high frequency and richness of Karyorelictea found in the present study.

Salinity, grain size, $\mathrm{pH}$, and the depth of water are reported as the main drivers of diversity in ciliate assemblages. For example, Liu and coworkers [50], in an investigation of the planktonic ciliate assemblage in a subtropical bay, found that salinity was one of the main factors that promoted changes in the ciliate community. Azovsky and Mazei [51] observed that granulometric composition of the sediment was the main factor controlling the diversity of benthic ciliate assemblages in Arctic sea sediments. $\mathrm{Xu}$ and Soininen [52] concluded that habitat type and salinity were the most important agents shaping ciliate communities in coastal areas of China.

Results of these studies showed that ciliates are usually distributed in small patches due to the heterogeneity of the interstitial environment. This patchy distribution may reflect bacterial activities including decomposition and dissolved oxygen reduction, which are a key factor for the interstitial biota. Predator-prey relationships within the meiofauna may also influence ciliate distribution, given documented experiments that show species and size-specific interactions within Ciliophora [50]. In the present study, the main abiotic factors that affected richness and diversity of the ciliate community were temperature, represented by the different seasons, levels of chlorophyll $a$, representing availability of food in the interstitial environment, and conductivity, a measurement of salinity fluctuation. Sediment granulometry, which appears to be an important abiotic factor shaping the ciliate community in other studies, does not change along the northern coast of Rio Grande do Sul state, and was thus not a factor that contributed to differences in species richness or diversity observed at our study sites. 
As mentioned above, some ciliate genera are very common inhabitants of the interstitial environment. For example, Peluronema has been found at high abundances in different parts of the world [43,53]. Karyorelicteans, such as Tracheloraphis, Trachelocerca, and Remanella, also have been frequently reported from different regions. Reports from the Mediterranean Sea showed that high abundance of Pleuronema was related with the presence of Remanella and both correlated with availability of bacteria and flagellates [43]. In the present study, a very high abundance of Pleuronema was observed at all sites during the whole study period (Table S1) and a similar pattern was displayed by Remanella. The occurrence of other genera was also related to environmental variables. For example, Frontonia and Amphisiella were correlated with high values of chlorophyll $a$, since these two ciliate genera are able to feed on microalgae, while the bacterivores Blepharisma and Spirostomum showed a strong relationship with urban development (Figure 8).

Statistical analyses showed that the composition of the ciliate community was significantly affected by season (temperature) and by the degree of urbanization in the beaches of Rio Grande do Sul state. Benthic ciliate communities were more similar during summer and fall, a result that has been reported in the literature [54,55]. The pattern observed here could be related to the higher input of organic matter that occurs in the summer period. During summer months, the beaches in Rio Grande do Sul state receive a high number of visitors that contribute to the increase of pollution and to a high input of organic matter to the ocean, since most of these beaches do not have sewage treatment. Even the beaches classified as having a low degree of urbanization, during summer months can triplicate the number of inhabitants. In the subsequent season, the population could be higher during the weekends, following a similar pattern observed during summer. This fluctuation in population could affect the ciliate community, leading to the pattern observed in the present study in which beaches with a high degree of urbanization had a different community composition in comparison with the other investigated sites.

The pattern of ciliate community composition throughout the investigated beaches in the present study is consistent with the intermediary disturbance theory (IDT), a well-known principle in ecology reported in the 1970s by Grime and Connell [56]. This theory postulates that intermediary levels of disturbance produces higher diversity than very high or very low disturbance levels. According to Connell [57], competitive exclusion in situations with very little disturbance leads to loss of diversity, but when disturbance is very high species with a slow growth rate are lost. Jiang and Patel [58] experimentally proved that the IDT is applicable to different microbial communities. Their results showed that ciliate communities were more diverse at an intermediate level of environmental disturbance in comparison with high or low disturbance. This could be explained by the fact that the strength of competition may decline with a considerable increase or decrease in disturbance [58].

In the present study, the composition of the ciliate community in the highly urbanized beaches was significantly different from the other types of sampled environments; however, it is possible that the disturbance remains at intermediary levels. This hypothesis may be in agreement with the phase classification proposed by McLachlan and Brown [1]. Considering the existence of four phases, and that Rio Grande do Sul beaches are at phase two, perturbations caused by the urbanization level of these coastal areas could be more or less intense. The consequence is that intermediary disturbance is reflected as different community composition in beaches classified as highly urbanized, sampled in this study.

Therefore, with the data obtained here and the considerations made, we assumed that the influence of urbanization on the ciliate assemblage is highly complex and indirect, involving more than one group from the interstitial community. It is possible that in areas where the impacts of human activities are greater, the influence is perceived similarly to what is predicted by the intermediary disturbance theory: Intermediary levels of disturbance increase diversity. On the other hand, in areas where there is less influence of urbanization, such as in the dune field area, the level of disturbance may be too low, leading to less richness. 
Any generalization is always difficult when it comes to ecological patterns; however, throughout this study (which seems to be the first of its kind for the assemblage of interstitial marine ciliates), we have shown that there is influence of urbanization degree in the structuring of the ciliate assemblage. Thus, long-term studies including data that cover a wider spectrum of latitude and urbanization levels are needed, since they can reduce noise and unravel clearer and more generalizable patterns.

Supplementary Materials: The following are available online at http://www.mdpi.com/1424-2818/12/1/16/s1. Table S1: List of ciliate species found in the coast of Rio Grande do Sul state (Brazil) between June 2016 and July 2017. Information on site of collection, season, and mean abundance of the species in the given season are provided. For abundance estimates different species in the same genus were counted under the genus name.

Author Contributions: Conceptualization, L.D.T. and L.R.P.U.; methodology, L.D.T. and L.R.P.U.; data collection, L.D.T.; data analyses, L.D.T. and P.M.A.F.; writing, original draft preparation, L.D.T.; writing, review and editing, L.R.P.U. and P.M.A.F. All authors have read and agreed to the published version of the manuscript.

Funding: This research received no external funding.

Acknowledgments: We would like to thank Charles Fernando dos Santos for his help with the statistical analyses, and two anonymous reviewers for their valuable suggestions. We also thank the Conselho Nacional de Pesquisa e Desenvolvimento (CNPq) for a scholarship granted to the first author.

Conflicts of Interest: The authors declare no conflict of interest.

\section{References}

1. McLachlan, A.; Brown, A. The Ecology of Sandy Shores, 2nd ed.; Academic Press: Amsterdan, The Netherlands, 2006; p. 392.

2. Lynn, D.H. The Ciliated Protozoa: Characterization, Classification, and Guide to the Literature, 3rd ed.; Springer: Berlin/Heidelberg, Germany, 2008; p. 605.

3. Wickham, S.; Gieseke, A.; Beminger, U.G. Benthic ciliate identification and enumeration: An improved methodology and its application. Aquat. Microb. Ecol. 2000, 22, 79-91. [CrossRef]

4. Giere, O. Meiobenthology: The Microscopic Motile Fauna of Aquatic Sediments, 2nd ed.; Springer: Berlin, Germany, 2009; p. 538.

5. Lana Paulo, C. O valor da biodiversidade e o impasse taxonômico: A diversidade marinha como estudo de caso. Desenvol. Meio Amb. 2003, 8, 97-104.

6. Albuquerque, E.F.; Pinto, A.P.B.; Perez, A.A.Q.; Veloso, V.G. Spatial and temporal changes in interstitial meiofauna on a sandy ocean beach of South America. Braz. J. Ocean. 2007, 55, 121-131. [CrossRef]

7. Gallucci, F.; Netto, S.A. Effects of the passage of cold fronts over a coastal site: An ecosystem approach. Mar. Ecol. Progr. Ser. 2004, 281, 79-92. [CrossRef]

8. Neves, F.M.; Bemvenuti, C.E. Variabilidade diária na zonação da macrofauna bentônica em praias arenosas do litoral norte do Rio Grande do Sul. Iheringia 2009, 99, 71-81. [CrossRef]

9. Neves, F.M.; de Sá Rodrigues da Silva, P.; Bemvenuti, C.E. Distribuição horizontal da macrofauna bentônica na Praia do Cassino, extremo sul do Brasil. Iheringia 2012, 102, 245-253. [CrossRef]

10. Kattar, M.R. Estudo dos protozoários ciliados psamófilos do litoral brasileiro. Bol. Zool. Biol. Mar. 1970, 27, 123-206. [CrossRef]

11. Paiva, T.S.; Albuquerque, A.F.C.; Borges, B.N.; Harada, M.L. Description and phylogeny of Tetrakeronopsis silvanetoi gen. nov., sp. nov. (Hypotrichia, Pseudokeronopsidae), a new benthic marine ciliate from Brazil. PLoS ONE 2014, 9, 2. [CrossRef]

12. Wanick, R.C.; Silva-Neto, I.D. Benthic ciliates from Sepetiba Bay (Rio de Janeiro, Brazil) with description of Pseudokeronopsis sepetibensis n. sp. (Spirotrichea: Urostylida). Zootaxa 2004, 587, 1-11. [CrossRef]

13. Vitousek, P.M.; Mooney, H.A.; Lubchenco, J.; Melillo, J.M. Human domination of earth's ecosystems. Science 1997, 277, 494-499. [CrossRef]

14. Adams, S.M. Assessing cause and effect of multiple stressors on marine systems. Mar. Pollut. Bull. 2005, 51, 649-657. [CrossRef] [PubMed]

15. Boyce, D.G.; Lewis, M.R.; Worm, B. Global phytoplankton decline over the past century. Nature 2010, 466, 591-596. [CrossRef] [PubMed] 
16. Martins, C.D.L.; Arantes, N.; Faveri, C.; Batista, M.B.; Oliveira, E.C.; Pagliosa, P.R.; Fonseca, A.L.; Nunes, J.M.C.; Chow, F.; Pereira, S.B.; et al. The impact of coastal urbanization on the structure of phytobenthic communities in southern Brazil. Mar. Pollut. Bull. 2012, 64, 772-778. [CrossRef] [PubMed]

17. Moura, N.S.V.; Moran, E.F.; Strohaecker, T.M.; Kunst, A.V. A urbanização na zona costeira: Processos locais e regionais e as transformações ambientais-O caso do Litoral Norte do Estado do Rio Grande do Sul, Brasil. Ciência Natura 2015, 37, 594-612. [CrossRef]

18. Gheskiere, T.; Vincx, M.; Weslawski, J.M.; Scapini, F.; Degraer, S. Meiofauna as descriptor of tourism-induced changes at sandy beaches. Mar. Environ. Res. 2005, 60, 245-265. [CrossRef]

19. Harguinteguy, C.A.; Cofré, M.N.; Pastor de Ward, C.T. Change in the meiofauna community structure of sandy beaches of the Nuevo Gulf (Chubut, Argentina). Papéis Avulsos Zoologia 2012, 52, 411-422. [CrossRef]

20. Tomazelli, L.J.; Villwock, J.A. Mapeamento geológico de planícies costeiras: O exemplo da costa do Rio Grande do Sul. Gravel 2005, 3, 109-115.

21. Toldo, E.E., Jr.; Almeida, L.E.S.B.; Nicoldi, J.L.; Absalonsen, L.; Gruber, N.L.S. O controle da deriva litorânea no desenvolvimento do campo de dunas e da antepraia no Litoral Médio do Rio Grande do Sul. Pesqu. Geociências 2006, 3, 35-42. [CrossRef]

22. Calliari, L.J.; Toldo, E.E.; Nicolodi, J.L. Rio Grande do Sul: Classificação geomorfológica. In Erosão e Progradação no Litoral Brasileiro, 1st ed.; Muehe, D., Ed.; Ministério do Meio Ambiente: Brasília, Brazil, 2006; pp. 438-445.

23. Ferraro, L.W.; Hasenack, H. Clima. In Ecossistemas e Biodiversidade do Litoral Norte do Rio Grande do Sul, 1st ed.; Würdig, N.L., Freitas, S.M.F., Eds.; Nova Prova: Porto Alegre, Brazil, 2009; pp. 26-31.

24. Sherr, E.B.; Sherr, B.F. Preservation and Storage of Samples for Enumeration of Heterotrophic Protists. In Handbook of Methods in Aquatic Microbial Ecology, 1st ed.; Kemp, P.F., Sherr, B.F., Sherr, E.B., Cole, J.J., Eds.; Lewis: Boca Raton, FL, USA, 1993; pp. 207-212.

25. Coelho, R.M.P. Métodos de coleta, preservação, contagem e determinação de biomassa em zooplâncton de águas epicontinentais. In Amostragem em Limnologia, 1st ed.; Bicudo, C.D.M., Bicudo, D.D.C., Eds.; RiMA: São Carlos, Brazil, 2004; pp. 149-165.

26. Small, E.B. A simple method for obtaining concentrated populations of protists from sediments. In Protocols in Protozoology, 1st ed.; Lee, J.J., Soldo, A.T., Eds.; Allen Press: Lawrence, KS, USA, 1992; p. A25.

27. Carey, P.G. Marine Interstitial Ciliates. An Illustrated Key, 1st ed.; Chapman \& Hall: London, UK, $1992 ;$ p. 351.

28. Dragesco, J.; Dragesco-Kernéis, A. Cilie's libres de l'Afrique intertropicale. Introduction a'la connaissanceet a'l'e'tude des Cilie's. Faune Tropicale 1986, 26, 1-559.

29. Xu, Y.; Li, J.; Gao, F.; Hu, X.; Al-Rasheid, K.A.S. Apotrachelocerca arenicola (Kahl, 1933) n. g., comb. n. (Protozoa, Ciliophora, Trachelocercidae): Morphology and Phylogeny. J. Euk. Mic. 2011, 58, 504-510. [CrossRef]

30. Xu, Y.; Miao, M.; Warren, A.; Song, W. Diversity of the karyorelictid ciliates: Remanella (Protozoa, Ciliophora, Karyorelictida) inhabiting intertidal areas of Qingdao, China, with descriptions of three species. Syst. Biodiv. 2012, 10, 207-219. [CrossRef]

31. Yan, Y.; Xu, Y.; Al-Farraj, S.A.; Al-Rasheid, K.A.S.; Song, W. Morphology and phylogeny of three trachelocercids (Protozoa, Ciliophora, Karyorelictea), with description of two new species and insight into the evolution of the family Trachelocercidae: Two New Ciliates and Evolution of Trachelocercids. Zool. J. Linnean Soc. 2016, 177, 306-319. [CrossRef]

32. Golterman, H.L.; Clymo, R.S.; Ohnstad, M.A.M. Methods for Physical and Chemical Analysis of Freshwater; Oxford Blackwell Scientific Publications IBP Handbook; Blackwell Scientific: Oxford, UK, 1978; p. 213.

33. Allen, S.E. Chemical Analysis of Ecological Materials, 2nd ed.; Blackwell Science Inc.: Oxford, UK, 1989 ; p. 565.

34. Magurran, A.E. Measuring Biological Diversity, 1st ed.; Wiley-Blackwell: Hoboken, NJ, USA, 2013; 264p.

35. Kolde, R. Pheatmap: Pretty Heatmaps. R Package Version 1.0.12. 2019. Available online: https://CRAN.Rproject.org/package=pheatmap (accessed on 9 December 2019).

36. Oksanen, J.; Blanchet, F.G.; Friendly, M.; Kindt, R.; Legendre, P.; McGlinn, D.; Minchin, P.R.; O’Hara, R.B.; Simpson, G.L.; Solymos, P.; et al. Vegan: Community Ecology Package. R Package Version 2.5-5. 2019. Available online: https://CRAN.R-project.org/package=vegan (accessed on 9 December 2019).

37. Pinheiro, J.; Bates, D.; DebRoy, S.; Sarkar, D.; R Core Team. Nlme: Linear and Nonlinear Mixed Effects Models. R Package Version 3.1-139. 2019. Available online: https://CRAN.R-project.org/package=nlme (accessed on 9 December 2019).

38. Legendre, P.; Legendre, L. Numerical Ecology, 3rd ed.; Elsevier: Amsterdam, The Netherlands, 2012; p. 1006. 
39. De Caceres, M.; Legendre, P. Associations between species and groups of sites: Indices and statistical inference. Ecology 2009, 90, 3566-3574. [CrossRef] [PubMed]

40. Dufrêne, M.; Legendre, P. Species assemblages and indicator species: The need for a flexible asymetrical approach. Ecol. Monog. 1997, 67, 345-366.

41. Azovsky, A.; Mazei, Y. Do microbes have macroecology? Large-scale patterns in the diversity and distribution of marine benthic ciliates. Glob. Ecol. Biogeogr. 2013, 22, 163-172. [CrossRef]

42. Fenchel, T. The ecology of marine microbenthos. IV. Structure and function of the benthic ecosystem. Ophelia 1969, 6, 1-182. [CrossRef]

43. Santangelo, G.; Lucchesi, P. The ciliated protozoa of an interstitial Mediterranean microcommunity. Hydrobiologia 1992, 230, 79-92. [CrossRef]

44. Burkovsky, I.V.; Mazei, Y. 21-Year dynamics of marine benthic ciliate community in the White Seaintertidal flat: Gradual or discrete? Russian J. Ecosyst. Ecol. 2017, 2, 1-15.

45. Al-Rasheid, K.A.S.; Sleigh, M.A. Distribution and Abundance of Interstitial Ciliates in Southampton Water in Relation to Physicochemical Conditions, Metal Pollution and the Availability of Food Organisms. Estuar. Coast. Shelf Sci. 1995, 41, 61-80. [CrossRef]

46. Al-Rasheid, K.A.S. New records of interstitial ciliates (Protozoa Ciliophora) from the Saudi coasts of the Red Sea. Trop. Zool. 2001, 14, 133-156. [CrossRef]

47. Azovsky, A.; Saburova, M.; Tikhonenkov, D.; Khazanova, K.; Esaulov, A.; Mazei, Y. Composition, diversity and distribution of microbenthos across the intertidal zones of Ryazhkov Island (the White Sea). Eur. J. Protist. 2013, 49, 500-515. [CrossRef] [PubMed]

48. Santangelo, G.; Lucchesi, P. Spatial distribution pattern of ciliated protozoa in a Mediterranean interstitial environment. Aquat. Microb. Ecol. 1995, 9, 47-54. [CrossRef]

49. Xu, Y.; Gao, S.; Hu, X.; Al-Rasheid, K.A.S.; Song, W. Phylogeny and systematic revision of the karyorelictid genus Remanella (Ciliophora, Karyorelictea) with descriptions of two new species. Eur. J. Protistol. 2013, 49, 438-452. [CrossRef] [PubMed]

50. Liu, H.; Chen, M.; Shen, P.; Huang, H.; Dai, M.; Qi, Z. A first description of ciliate assemblages in a subtropical eutrophic bay, South China Sea: Species assemblage and environmental correlates. Aquat. Living Resour. 2016, 29, 304. [CrossRef]

51. Azovsky, A.I.; Mazei, Y.A. Diversity and distribution of free-living ciliates from High-Artic Kara sea sediments. Protist 2018, 169, 141-157. [CrossRef]

52. $\mathrm{Xu}, \mathrm{Y}$; S Soininem, J. Spatial patterns of functional diversity and composition in marine benthic ciliates along the coast of China. MEPS 2019, 627, 49-60. [CrossRef]

53. Mazei, Y.A.; Burkovsky, I.V. Species composition of benthic ciliate community in the Chernaya River estuary (Kandalaksha Bay, White Sea) with a total checklist of the White Sea benthic ciliate fauna. Protistology 2015, 4, 107-120.

54. Epstein, S.S.; Gallagher, E.D. Evidence for facilitation and inhibition of ciliate population growth by meiofauna and macrofauna on a temperate zone sandflat. J. Exp. Mar. Biol. Ecol. 1992, 155, 27-39. [CrossRef]

55. Xu, Y.; Stoeck, T.; Forster, D.; Ma, Z.; Zhang, L.; Fan, X. Environmental status assessment using biological traits analyses and functional diversity indices of benthic ciliate communities. Mar. Poll. Bull. 2018, 131, 646-654. [CrossRef]

56. Wilkinson, D.M. The Disturbing History of Intermediate Disturbance. Oikos 1999, 84, 145-147. [CrossRef]

57. Connell, J.H. Diversity in tropical rain forests and coral reefs. Science 1978, 199, 1302-1310. [CrossRef] [PubMed]

58. Jiang, L.; Patel, S.N. Community assembly in the presence of disturbance: A microcosm experiment. Ecology 2008, 89, 1931-1940. [CrossRef] [PubMed]

(C) 2019 by the authors. Licensee MDPI, Basel, Switzerland. This article is an open access article distributed under the terms and conditions of the Creative Commons Attribution (CC BY) license (http://creativecommons.org/licenses/by/4.0/). 